\title{
Benefits of dance in the quality of life of people with depression: a systematic review
}

\author{
Givaldo José dos Santos ${ }^{1 *}$; Valdir Eneias de Melo²$^{2}$ Cleiton Cavalcanti do Nascimento ${ }^{3}$; Morgana \\ Gabriela dos Santos Lima Bressiani ${ }^{4}$
}

1 Specialist in Mental Health Alcohol and Other Drugs at Faculdade Novo Horizonte - FNV. Graduated in Psychology UNIVISA.

2 Psychologist, Master's degree from the Catholic University of Pernambuco - UNICAP.

3 Psychologist Specialist in Mental Health Alcohol and Other Drugs at Faculdade Novo Horizonte - FNV

4 Psychologist, Specialist in Cognitive Behavioral Therapy - PUC - RS

E-mail adresses: santosgivaldo2015@gmail (Givaldo José dos Santos), melovaldir21@hotmail.com (Valdir Eneias de Melo).

${ }^{*}$ Corresponding author

\section{To cite this article:}

Santos, G.J.; Melo, V.E.; Nascimento, C.C.; Bressiani, M.G.S.L. Benefits of dance in the quality of life of people with depression: a systematic review. International Journal of Sciences. Vol. 2, No. 3, 2021, pp.94-100. ISSN 2763-5392.

Received: 10 25, 2021; Accepted: 10 25, 2021; Published: 11 03, 2021

\begin{abstract}
Dance, which today is a physical activity, emerged as a form of entertainment for primitive peoples. Through its people have always sought pleasure. Today dance is recognized as an important source of quality of life, promotes social interaction, brings psychological benefits and is a potential factor related to increasing people's life expectancy. The general objective of this study is to identify in the scientific literature studies conducted on the benefits of dance for the quality of life of people with depression and the main findings that can be extracted from the current literature on such benefits, considering studies conducted in the last 10 (ten) years. The study also brings specific objectives, namely: quantitatively analyzing, in the scientific field, the interest on the relationship of dance with improvement of depression; briefly know the history of dance; know concepts and basic aspects for understanding what depression is, understand the importance of the adoption of a pleasurable physical activity for people with depression. The study adopts the method of systematic review of the literature in the electronic database Latin American and Caribbean Literature on Health Sciences (Lilacs), Scientific Electronic Library Online (SciELO) and National Library of Medicine National Institutes of Health (Medline/PubMed), through the search for the descriptors: "dance", "depression", "quality of life", with the use of the logical operator "and" or "e" to make the combination of terms in the results. The inclusion criteria are the studies that have been published in Brazil in the last 10 (ten) years that have the associated descriptors present in the title and/or abstract. The results obtained add up to 4 articles in the LILAS library, no articles in the PUBMED library and 2 articles in SCIELO, one of which is repeated to lilacs. The identified studies investigate varied themes in which depression is one of the factors evaluated, that is, directly the relationship between dance and depression was not identified in the literature, however, in the studies in which it was analyzed along with other factors and pathologies, the results of dance for depression proved beneficial, suggesting that the theme is more studied, mainly in research in the areas of physical education and health.
\end{abstract}

Keywords: Dance. Quality of Life. Depression. Mental Health.

\section{Introduction}

According to Toneli (2007), there is no way to specify exactly the origin of the first dances, what is known, is that since prehistory dance movements were already practiced in rituals that aimed to make a connection between men and divinity. According to the author, notes of dance practices are found in the Bible, being the Hebrew dance that had no cultural originality, was something spontaneous and natural among the people and happened in the commemorative festivals.

Therefore, although I have no news of when the origin of dance is marked, it is known that since prehistory it is present in the life of man. 
Mazo, Lopes and Benedetti (2009) mention that dance since the beginning of the human race was present in people's lives and was included in the very evolution of society, undergoing major changes over time, and may even be related to historical moments from which various types of dances arise that are practiced today.

Dance for the ancient peoples, according to Hass and Garcia (2006), was considered as a manifestation. Humans danced to call rain, to ask for the cure of some diseases, to thank and even in funeral rituals.

According to the authors dance has always been present in all the events of the ancient peoples in Greece, in Rome, in Egypt, in short, it was the most significant activity for them in their rituals and festivities.

Dance is practiced today as an option of physical activity; however, it is also an entertainment form in which people seek pleasure, quality of life, social integration, psychological and increase life expectancy.

In the educational sphere, according to Almeida (2005), dance as a culture of the movement has been claimed as one of the bodily practices that physical education is used in its pedagogical function.

Almeida (2005) explains that the dance activity promotes the pleasure of those who dance, for the person who is dancing together, for the music you hear and feel to dance, for the place where you are dancing, among countless other ways of feeling pleasure.

Toneli (2007) emphasizes that dance practice has numerous benefits, helps in improving quality of life, because it is a low impact activity that contributes to health, improves self-esteem and has as a role the development of socialization and integration among individuals, being therefore widely practiced as leisure and as a physical activity nowadays.

According to Hass and Garcia (2006, p.139):

"Dance is understood as an art that means gestural and facial expressions through body movements, emotions felt from a certain state of mind."

Therefore, dance is a way of communicating and expressing emotions. Almeida (2005) narrates that dance is a form of expression and communication capable of stimulating human abilities when incorporated into oral language. In this context, while words are formed by letters, body movements are formed by elements of expression that are capable of stimulating and developing psychic activities according to their content and the way these movements are experienced, as well as words, which can positively or negatively influence the psychic structure of the individual.

According to Mazo, Lopes and Benedetti (2009), dance can be practiced at any age, regardless of gender, anywhere, there are no restrictions, at most adaptations to the conditions of each person, it is a subsequence of movements performed in varied musical rhythms through which feelings and emotions are expressed.

Dance as a physical activity nowadays, according to Marbá, Silva and Guimarães (2016), improves the disposition for day-to-day activities and provides muscle strength, body aesthetics and self-esteem to practitioners, through movements that are performed at different rhythms.

With a subsequence of somatic movements to the sound of songs, people express feelings and emotions so that they feel better, more active and happier, so dance is related to alternative therapies for the treatment of psychosomatic diseases, among which, with great emphasis, depression is already considered a disease of the 21 st century.

The present study aims to answer the question: What are the findings of the scientific literature on the benefits of dance for the quality of life of people with depression?

The hypothesis of the study is that the scientific literature has been exploring the theme in order to identify and verify direct benefits that dancing provides to people with depression, improving their physical and mental health conditions.

Almeida (2005) also states that dance is a healthy activity that brings several benefits, improves physical capacity, reduces depressive states. What everyone's looking for on a dance floor is pleasure.

Dance, as a form of language, according to Almeida (2005), is composed by other artistic languages that are part with it, music, performing arts, literature and even the visual arts, because in the elaboration of dance shows it relates to all these other artistic expressions.

The general objective of this study is, therefore, to identify the studies conducted in the scientific field about the benefits of dance for the quality of life of people with depression and what are the main findings that can be extracted from the current literature on such benefits, considering studies conducted in the last 5 (five) years.

The specific objectives also stand out: quantitatively analyze the interest and concern in the scientific field about the relationship of dance with improvement of depression; briefly know the history of dance; to know concepts and basic aspects for understanding what depression is, to understand the importance of the adoption of a pleasurable physical activity for people with depression.

Today it is already considered as fact the need to practice physical activities to have good health, of course this is associated with the adoption of good life habits, such as a good diet, quality sleep, but the practice of physical education is always required when thinking about improving life habits.

According to Marbá, Silva and Guimarães (2016) this is because people are increasingly aware of the positive results in relation to quality of life when adopting the practice of physical activities.

And in this context, dance is a form of physical activity, leisure and entertainment that provides quality of life, social integration, psychological and greater life expectancy.

According to Marbá, Silva and Guimarães (2016), the search for physical activity to improve the quality of life has been growing and dance, because it is a pleasurable activity, has become a great option for people who want to change their lifestyle in search of well-being and physical and mental health.

Mazo, Lopes and Benetedetti (2009) consider that dance makes it possible to work body and mind simultaneously and contributes to the expressions and creativity of the elderly who 
come to have more care for themselves, identifying their limits and personal restrictions and their emotions.

Szuster (2011) states that dance is a type of physical activity that allows the individual to improve his/her physical function, health and well-being. According to him, practicing physical exercises favors both the aesthetic part of the individual, as well as well-being, making those who practice feel good, have a better health and more disposition. And, dance because it is a physical activity that is also related to pleasure and fun is an important option for those who wish to take good care of physical and mental health.

In the gyms the search for dance is great. One of the reasons is the fact that people are overweight and seek ways to achieve results that promote self-esteem, thus aiming at a good appearance of their body image. The disposition of those who practice physical activity can increase, facilitating the performance of daily tasks, without giving space to sedentary lifestyle and even diseases.

When researching women who choose dance as a physical activity Marbá, Silva and Guimarães $(2016$, p.8) state:

(...) the research participants seek dance in search of a better quality of life, practicing physical activities that give pleasure and, in this case, for the students, pleasure is found in dance. It can also be emphasized that the participants acquired numerous benefits with this stimulating activity for health, whether physical or psychological.

Marbá, Silva and Guimarães (2016, p.4) highlight that "dance is a physical activity that improves health, can trigger various benefits and improves the lifestyle of the individual, regardless of age, and is an excellent promoter of quality of life".

The choice of this theme is justified, first, by the fact that depression is becoming one of the most common diseases today and whose consequences are harmful, affecting from the quality of life of the sick person as well as their family members, with the cost it generates to public health and even by the relationship it has with other factors that directly affect society such as the rate of suicide and violence.

As dance is an activity that usually gives pleasure and those who practice and like feel better in all aspects, physical, emotional, social and psychological, it is relevant that physical education professionals, and students in the area, deepen the theme so that in their professional practices they know how to recognize the relationship of dance with the improvement of the quality of life of people with depression, so that they can indicate physical activity in an appropriate way, encourage dance in certain groups, among other activities that contribute to a professional practice that considers the real health benefits.

It is, therefore, a theme of great relevance, both for academia and for society.

\section{Methodology}

\subsection{Type of search}

This is a systematic review of scientific literature that will make a synthesis of articles published in the last 10 years on the subject. The research will be carried out in the electronic databases Latin American and Caribbean Literature on Health Sciences (Lilacs), Scientific Electronic Library Online (SciELO) and National Library of Medicine National Institutes of Health (Medline/PubMed), using the following descriptors, in Portuguese: "dance", "depression", "quality of life", in addition to the Boolean operator "and" or "e" for the combination of the terms.

\subsection{Inclusion and exclusion criteria}

Theses and articles published in journals from 2009 to 2019 will be included, comprising a period of 10 years, including those written in Portuguese and published in Brazil and that specifically address the relationship between dance and the quality of life of people with depression at all ages. From the selection by title and later by abstracts, those studies that do not meet the inclusion criteria mentioned will be excluded.

\section{Results and Discussion}

The research carried out in lilacs, PubMed and SciELO repositories by the descriptors dance + quality of life + depression, considering the search for indexes by title and abstracts did not report any results.

With the association of only the descriptors dance + depression, excluding quality of life, 4 articles were reported in LILACS, none in PUBMED and 2 in SCIELO (Table 1).

Table 1. Articles reported by the research on the basis of LILACS

\begin{tabular}{|c|c|c|c|c|}
\hline Source & Year & Author(s) & Title & Description \\
\hline $\begin{array}{c}\text { Rev. } \\
\text { Kairós / } \\
\text { 13th } \\
\text { National } \\
\text { Congress } \\
\text { of } \\
\text { Scientific } \\
\text { Initiation, } \\
\text { Campinas } \\
\text {,2013. }\end{array}$ & 2015 & $\begin{array}{l}\text { Hoyer, Bruna } \\
\text { Perez } \\
\text { Broadbent; } \\
\text { Theodore, } \\
\text { Vanessa Jesus } \\
\text { Rodrigues; } \\
\text { Borges, Sheila } \\
\text { de Melo. }\end{array}$ & $\begin{array}{c}\text { The } \\
\text { Influence } \\
\text { of Belly } \\
\text { Dance on } \\
\text { depressive } \\
\text { symptoms } \\
\text { in } \\
\text { community } \\
\text { women }\end{array}$ & $\begin{array}{c}\text { A } \\
\text { randomized } \\
\text { "blind" trial } \\
\text { study that } \\
\text { evaluated the } \\
\text { influence of } \\
\text { belly dance } \\
\text { (DV) on } \\
\text { depressive } \\
\text { symptoms in } \\
\text { community } \\
\text { members, } \\
\text { divided into } \\
\text { two groups: } \\
\text { I-control and } \\
\text { II- } \\
\text { intervention; } \\
\text { (T0) and after } \\
\text { (IT) the } \\
\text { intervention } \\
\text { with DV. We } \\
\text { used } \\
\text { abbreviated }\end{array}$ \\
\hline
\end{tabular}




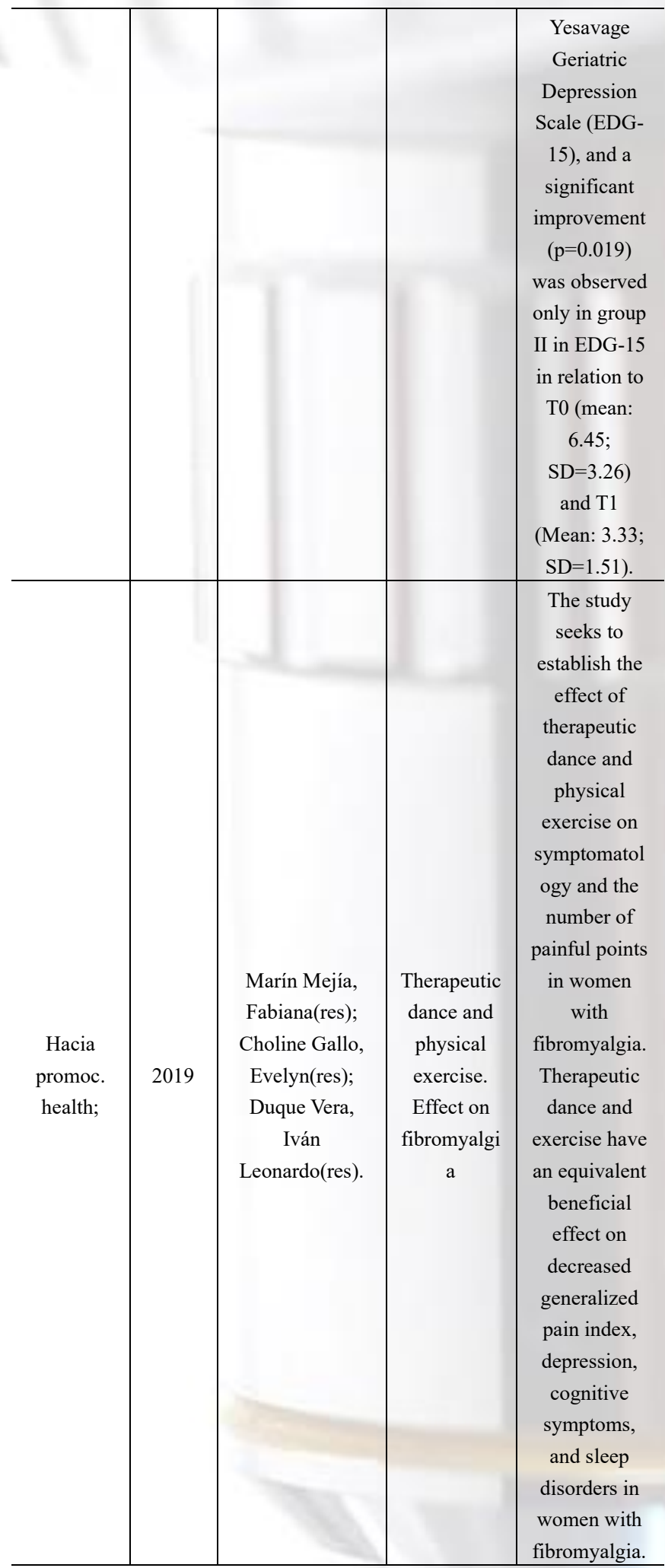

Source: own elaboration

Of the studies identified, two are related to evaluations of the impact of dance on the emotional/mental health of the elderly, one evaluates the impact of dance on fibromyalgia in which one of the factors evaluated is depression and the other does not directly address the impact of dance, but only makes a survey on a specific dance audience.
Hoyer et al. (2015) identify the main biopsychosocial problems of the elderly, reporting that dance tends to improve the physical and functional capacity of this population, because it allows the elderly to rediscover abilities and pleasure, besides being able to extracted emotions and feelings through rhythms and movement with the body.

According to the study, dance is able to activate certain areas of the brain that are related to various functions, memory, perception, emotions and motor skills of the individuals who practice it. The skills affected by dance movements reflect in procedural, motor and cognitive memories.

Therefore, when dancing increases the capacity of the body that needs to encode the movements, and according to Hoyer and such (2017), this process significantly reflects in the gait of the elderly, improving the balance.

The study cited uses the abbreviated Yesavage Geriatric Depression Scale (EDG-15), and a significant improvement in the sample of old women who practice belly dancing was observed.

The authors, when identifying anxiolytic and antidepressant effects of belly dance for this group of old women, consider that dance can be a preventive and therapeutic resource.

Trevisan et al. (2017) when investigating the mood states of students participating in the Royal Academy of Dance Exams cite several studies that highlight the benefits of physical activities for reducing stress, anxiety, depression and hostility, in addition to improving mood, but do not mention studies specifically about dance.

These authors highlight that, for the regulation of mood, physical exercise proves to be an efficient resource, whose benefits are very widespread among health professionals, the media and researchers, denoting the academic importance of the subject, and analyzing an audience of dance students.

According to the study, dance practices act favorably in the perception of positive affective states of the sample, acting in the reduction of factors such as depression, anger and mental confusion, thus proving the potential of dance practice to interact positively in the mood of dance students, which was the object of study.

The study by Gouvêa et al. (2017) which investigates the impact of senior dance on cognitive, motor and quality of the elderly, cites cognitive ability as one of the determinants of the quality of life of the elderly. According to them, losses in cognitive functions with age result in impairment in physical, social and emotional functioning.

According to the study cited, in dance the elderly work physically with planning, make decisions and learn to monitor their own movements. These tasks help to promote, develop and maintain their functional capabilities as part of a systematized set of choreographies that are adapted for them, considering their limitations and needs.

According to Gouvêa et al (2017), cognitive deficit is associated with altered mobility, spatial disorientation and deterioration of the executive functions of the elderly, and the practice of physical exercises, such as dance, is capable 
of improving mental health and contributing to the prevention of disorders common to aging such as depression and even dementia.

Thus, to promote healthy aging, the author points out that dance has been much sought after as physical activity. Because it is an art of body expression and is directly related to people's state of mind, it is a very indicated physical activity when seeking quality of life, especially for elderly people.

In the specific case of the elderly, the fact that dance is related to improvements in mobility and psychological problems, dance is even more sought after as a physical activity nowadays. Dance has been responsible for improving the self-esteem of sedentary elderly, making them more physically active when practicing the activity.

According to Gouvêa et al., (2017) there is evidence that dance as a physical activity, because it presents in its essence an intense cognitive demand, requiring the memorization of movement sequences and execution of patterns of attention sustained by intentional changes in movements, present many benefits for the health of the elderly, not only to the strengthening of muscle systems, cardiovascular and cardiovascular system, but also to the better functioning of the central nervous system, through engagement in executive control processes.

According to the authors, through body expression as a dance movement, the elderly can benefit both in social, intellectual and physical life. They warn that the results in the sample evaluated by them were not significant because one should take into account the period of the intervention, which, in the case of their study, may not have been sufficient to promote changes in the psychological parameter of the elderly participants, since dance integrates physiological, psychological and sociological components, besides providing an opportunity to convivialist with music, which is not possible in a very short space of time (Table 2).

Table 2. Articles reported by the research on the basis of SCIELO

\begin{tabular}{|c|c|c|c|c|}
\hline Source & Year & Author(s) & Title & Description \\
\hline $\begin{array}{l}\text { Rev } \\
\text { Bras } \\
\text { Med } \\
\text { Sport }\end{array}$ & 2020 & $\begin{array}{l}\text { Tillmann, Cristina } \\
\text { Ana; Swarowsky, } \\
\text { Alessandra; } \\
\text { Andrade, } \\
\text { Alexandro; } \\
\text { Moratelli, Jessica; } \\
\text { Boing, Leonessa; } \\
\text { Vieira, Melissa de } \\
\text { Carvalho Souza; } \\
\text { Piglet, Alice } \\
\text { Erwig; Adriana } \\
\text { Coutinho de } \\
\text { Azevedo, } \\
\text { Guimarães }\end{array}$ & $\begin{array}{c}\text { The impact } \\
\text { of Brazilian } \\
\text { samba on } \\
\text { Parkinson's } \\
\text { disease: } \\
\text { analysis } \\
\text { through the } \\
\text { subtypes of } \\
\text { the disease }\end{array}$ & $\begin{array}{l}\text { People with } \\
\text { Parkinson's } \\
\text { disease } \\
\text { constantly } \\
\text { have low } \\
\text { levels of } \\
\text { physical } \\
\text { activity. } \\
\text { Dance has } \\
\text { become } \\
\text { increasingly } \\
\text { important for } \\
\text { the treatment } \\
\text { of the disease } \\
\text { and can help } \\
\text { improve non- } \\
\text { motor } \\
\text { symptoms, }\end{array}$ \\
\hline
\end{tabular}

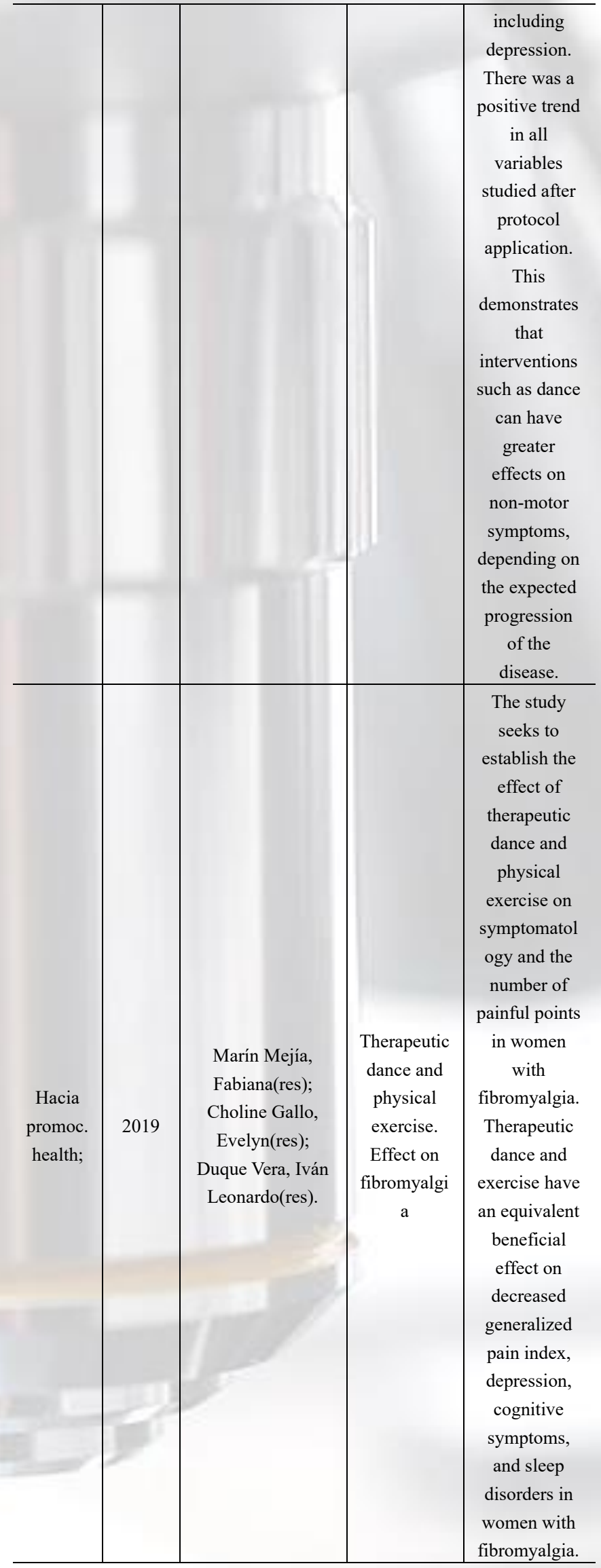

Source: own elaboration 
From the studies reported by the SCIELO database, one of them was repeated, which investigates the relationship between dance and fibromyalgia is the same as reported by lilacs database. The other study reported on this basis investigates the relationship between dance and Parkinson's disease factors, identifying that interventions such as dance may have greater effects on non-motor symptoms of the disease, depending on progression, including depression.

According to a recent study by Tillman et al. (2020) people with Parkinson's disease constantly have low levels of physical activity, the study identifies that dance has become increasingly important for the treatment of this disease because it can help improve non-motor symptoms such as sleep, fatigue and depression.

The study by Marín-Mejía attests that therapeutic dance and physical exercise have beneficial effects both in reducing the generalized pain index of women with fibromyalgia, as well as in depression and cognitive symptoms and sleep disorders of these elderly patients.

The study by Hoyer et al (2017) points out evidence that the dance movement promotes positive changes that reflect on the expression and communication of the elderly, softens negative feelings such as fear and isolation, contributing to the development of self-esteem.

It is possible to identify that the theme relating dance as a therapy for depression is still very little explored in the scientific literature, including no specific studies were identified and in the few studies published in Brazil, in which depression is considered as a factor along with other investigations, in Portuguese, whether directly or indirectly, dance appears as a positive factor for satisfactory results in depression, quality of life, among other emotional and mental health factors, which is why a deeper look at this relationship becomes even more necessary.

Trevisan et al. (2017) mention that further studies are needed to improve approaches to subjective states involving dance practices and training, as well as performance evaluations, which are aspects still little explored in the academic sphere.

As noted in the present study, despite the recognition of the importance of dance as a therapy for depression associated in an incipient way in studies on other topics, the practice of dance and all aspects that involve this activity as therapy for depression, therefore, it is not yet addressed directly in the scientific field.

\section{Conclusions}

This study fulfills the proposed objective by identifying benefits of dance in improving depression through studies that focused on investigations of other diseases such as Parkinson's and Fibromyalgia and other sets of quality-oflife factors, especially in the elderly.

The proposed research, associating the three proposed descriptors: dance, quality of life and depression, did not report results, to adapt the study, the research was carried out again associating only two of the descriptors dance and depression, obtaining the result of 4 articles meeting the inclusion criteria in the base of LILAS, none in PUBMED and 2 in SCIELO.

None of the studies directly addresses the relationship between dance and depression, but all of the studies evaluate depression as one of the points or factors of investigation in conjunction with other factors or pathologies, always with positive results in relation to improvement, even identifying a relationship of improvement with other factors in health.

The studies reported in the research show that physical and mental capacities are in synergy with quality of life and that dance, as a physical activity, due to its characteristics of providing, pleasure, psychosocial interaction, improves quality of life and consequently depression, however, it is necessary that the activity be further studied with the focus of establishing its relations with improvements, as it was noticed that, in one of the studies, the factor time of analysis is relevant, the type of dance, the relationship with other age groups, finally, several specific points need to be raised and analyzed in order to accurately measure the benefits of dance in the improvement of depression, and more, so that it can be more and more available of this activity to meet a population that is increasingly depressed.

However, the public identified in the majority in the studies is that of the elderly, leaving open beyond the need to deepen the areas of health and physical education in specific studies of this relationship, the need to investigate audiences of different ages since Depression has become a pathology present in all age groups.

\section{References}

[1] ALMEIDA, Cleuza Maria de. Um Olhar sobre a Prática da Dança de Salão. Rev. Movimento \& Percepção, Espírito Santo do Pinhal, SP, v.5, n. 6, jan./jun. 2005.

[2] GOUVÊA, José Alípio Garcia; ANTUNES, Mateus Dias; BORTOLOZZI, Flavio; MARQUES, Andrea Grano; BERTOLINI, Sônia Maria Marques Gomes. Impacto da dança sênior nos parâmetros emocionais, motores e qualidade de vida de idosos. Rev. RENE; 18 (1), jan.-fev. 2017.

[3] HASS, Aline Nogueira e GARCIA, Ângela. Ritmo e dança. Canoas. Ed. ULBRA, 2006.

[4] HOYER, Bruna Perez Broadbent; TEODORO, Vanessa Jesus Rodrigues; BORGES, Sheila de Melo. A Influência da Dança do Ventre nos sintomas depressivos em idosas da comunidade. Hacia promoc. salud; 24 (1): 13 nov. 2019.

[5] MARBÁ, Romolo Falcão; SILVA, Geusiane Soares da Silva; GUIMARÃES, Thamara Barbosa. Dança na promoção da saúde e melhoria da qualidade de vida. Revista Científica do ITPAC, 9 (1), Pub.3, Araguaína, fev. 2016.

[6] MARÍN MEJÍA, Fabiana; COLINA GALLO, Evelyn; DUQUE VERA, Iván Leonardo. Dança terapéutica e exercício físico: efeito sobre a fibromialgia. Hacia promoc. Salud, 24 (1): 13 nov. 2019.

[7] MAZO, Giovanna Zarpellon; LOPES, Marize Amorin; BENEDETTI, Tânia Bertoldo. Atividade física e o idoso: 
Concepção Gerontologia, 2009.

[8] SZUSTER, Lia. Estudo qualitativo sobre a dança como atividade física em mulheres acima 50 anos.69 f. (Monografia de Bacharel em Educação Física) Porto Alegre - RS. 2011. Disponível em: < https://www.lume.ufrgs.br/handle/10183/39328.>

Acesso em: 18 de novembro de 2019.

[9] TILLMANN, Ana Cristina; SWAROWSKY, Alessandra; ANDRADE, Alexandro; MORATELLI, Jéssica; BOING, Leonessa; VIEIRA, Melissa de Carvalho Souza; LEITÃO, Alice Erwig; GUIMARÃES, Adriana Coutinho de Azevedo. O impacto do samba brasileiro na doença de Parkinson: análise através dos subtipos da doença. Rev. Bras Med Esporte, 26 (1), jan-fev, 2020.

[10] TONELI, Poliana. D. Dança de Salão: Instrumento para a qualidade de vida no trabalho. Assis, 2007.

[11] TREVISAN, Priscila Raquel Tedesco da Costa; SCHWARTZ, Gisele Maria; AURIEMO, Danielle Ferreira; PALHARES, Marcelo Fadori Soares; CATIB, Norma Ornelas Montebugnoli; RIBEIRO, Ivana de Campos. Avaliação de Estados de Humor nos Exames da Royal Academy of Dance. Psicol. teor. Pesqui. 33; 2017. 